\title{
MODEL SPACE TIME AUTOREGRESSIVE INTEGRATED (STARI) UNTUK DATA DEBIT AIR SUNGAI CITARUM DI PROVINSI JAWA BARAT
}

\author{
Space Time Autoregressive Integrated (STARI) Model for Citarum River \\ Water Discharge Data in West Java Province
}

\author{
Mutik Alawiyah $^{1}$, Dianne Amor Kusuma ${ }^{2}$, Budi Nurani Ruchjana ${ }^{3 *}$ \\ 1,2,3 Departemen Matematika Fakultas Matematika dan Ilmu Pengetahuan Alam, Universitas Padjadjaran \\ Jalan Raya Bandung Sumedang km 21 Jatinanagor, Sumedang, 45363, Indonesia

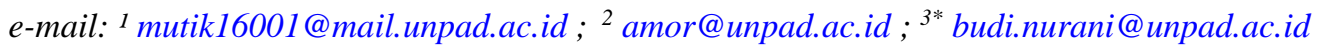

Corresponding author*

\begin{abstract}
Abstrak
Curah hujan di Jawa Barat pada musim hujan cukup tinggi. Hal ini menyebabkan daerah di sekitar Daerah Aliran Sungai (DAS) Citarum mengalami banjir. Namun, pada musim kemarau DAS Citarum mengalami kekeringan. Disamping itu, perubahan debit air sungai Citarum juga mengalami perubahan antar lokasi. Untuk melakukan peramalan pada data debit air sungai Citarum dapat digunakan model Space Time Autoregressive Integrated (STARI). Pada paper ini, model STARI diterapkan untuk data debit air sungai Citarum di keempat lokasi pengamatan. Berdasarkan kestasioneran data menunjukkan bahwa data tidak stasioner sehingga harus dilakukan proses differencing terlebih dahulu sebanyak 1 kali. Identifikasi orde model AR adalah satu karena plot PACF terpotong pada lag 1. Lag spasial yang digunakan pada paper ini adalah lag spasial 2, sehingga debit air sungai Citarum dapat diprediksi dengan model STARI $(2,1,1)$. Penaksiran parameter model STARI $(2,1,1)$ dengan matriks bobot seragam ditaksir dengan metode MLE dengan bantuan software R dan S-Plus 8.0. Hasil prediksi debit air sungai Citarum yang akan datang untuk keempat lokasi pengamatan digunakan model STARI $(2,1,1)$ dengan MAPE yang kurang dari $10 \%$, dengan demikian model STARI $(2,1,1)$ dapat direkomendasikan untuk memprediksi data debit air sungai Citarum.
\end{abstract}

Kata Kunci : Debit Air Sungai Citarum, Lag Spasial, Matriks Bobot, Model STARI

\begin{abstract}
Rainfall in West Java during the rainy season is quite high. This causes the area around the watershed to experience flooding. However, in the dry season the Citarum watershed experiences drought. Changes in the Citarum river water discharge from time to time is not only influenced by time but also influenced by the location around it. To forecast the Citarum river water discharge data, the Space Time Autoregressive Integrated (STARI) model can be used. In this study, the STARI model was applied to the Citarum river water discharge data at all four observation sites. Based on the stationary data, it showed that the data is not stationary, so the differencing process must first be done 1 time. The identification of the order of the AR model was one because the PACF plot was truncated in lag 1. The spatial lag used in this study was the spatial lag of order 2, so the Citarum river water discharge could be predicted with the STARI model. Estimation of STARI) model parameters with a uniform weight matrix was estimated by the MLE method with the help of R and S-Plus 8.0 softwares. STARI model with MAPE less than 10\% was used for predicting Citarum river water discharge data for the four observation locations, thus the STARI model can be recommended to predict Citarum river water discharge data.
\end{abstract}

Keywords: Citarum River Water Discharge, Spatial Lag, Weight Matrix, STARI Model 


\section{PENDAHULUAN}

DAS Citarum memiliki peranan penting dalam kehidupan masyarakat di Jawa Barat. Sungai Citarum digunakan sebagai sumber energi primer 3 PLTA (Saguling, Cirata dan Jatiluhur) yang menghasilkan hampir 2000 MW listrik yang menjadi penyangga pasokan listrik interkoneksi Jawa, Madura dan Bali. Selain itu, Sungai Citarum sebagai sumber bahan baku air minum sebanyak $80 \%$, sumber irigasi sebesar $86,70 \%$, sumber air perkotaan sebesar 0,0370\% dan pemasok air kegiatan rumah tangga dan industri sebanyak $2 \%$ [1].

Curah hujan di Jawa Barat pada musim hujan cukup tinggi. Hal ini menyebabkan daerah di sekitar DAS Citarum mengalami banjir. Salah satu penyebab banjir ini adalah debit air sungai meningkat [13]. Namun, pada musim kemarau DAS Citarum mengalami penurunan debit air sehingga menyebabkan daerah di sekitar DAS Citarum mengalami kekeringan [14].

Debit air sungai Citarum dari waktu ke waktu mengalami banyak perubahan. Data yang berhubungan dengan waktu yaitu data time series. Data debit air sungai Citarum menggunakan analisis time series untuk membuat pemodelan maupun peramalan. Peramalan yang baik adalah pemodelan yang tepat dan model yang baik yaitu model yang dapat dijelaskan dengan sederhana [10]. Salah satu model time series yang digunakan adalah model time series univariat linear yang disebut model Autoregressive (AR). Apabila model AR tidak stasioner maka harus dilakukan proses pembedaan (differencing) sehingga model AR berubah menjadi model Autoregressive Integrated (ARI). Selain dipengaruhi oleh waktu, debit air sungai Citarum di suatu lokasi dipengaruhi juga oleh debit air sungai Citarum di lokasi sekitarnya. Berdasarkan lokasinya, debit air sungai Citarum dapat dikaji dengan kajian data spasial. Data spasial adalah data yang diamati berdasarkan lokasi yang berdekatan dan memiliki karakteristik lokasi yang mirip [9].

Penelitian mengenai model time series univariat dilakukan [11], sedangkan gabungan dari model time series dengan model spasial secara simultan dinamakan model spasial-waktu (space time). Salah satu model space time yang sering digunakan adalah model Space Time Autoregressive (STAR). Model STAR stasioner pertama kali dikaji [2] berupa model time series multivariat yang menyatakan pengamatan di suatu lokasi pada waktu $t$ dipengaruhi oleh pengamatan waktu $t$ tersebut dengan melibatkan pengaruh lokasi-lokasi di sekitarnya. Sedangkan [15] mengembangkan model tersebut secara lebih realistik dengan memberikan pengaruh satu waktu sebelumnya atau lag waktu 1. Penelitian model STAR dilakukan oleh [15] dengan asumsi lokasi-lokasi memiliki karakteristik yang homogen. Penelitian lain tentang model STAR dilakukan [9] khususnya pada matriks bobot lokasi yang dilanjutkan oleh [13] dan [12] melakukan penerapan model STAR $(1,1)$ pada produktivitas minyak bumi. Apabila fenomena AR tidak stasioner, maka untuk kajian model space time terlebih dulu perlu distasionerkan melalui proses differencing menjadi AR Integrated (ARI), sehingga model STAR yang digunakan menjadi model Space Time Autoregressive Integrated (STARI) atau Space Time Autoregressive Moving Average (STARIMA), yang dikembangkan oleh [15].

Selanjutnya [5], [6], [17] mengembangkan model STAR menjadi model Generalized Space Time Autoregressive (GSTAR) dengan asumsi karakteristik lokasi bersifat heterogen dan masing-masing lokasi memiliki parameter yang berbeda satu sama lain dengan penaksiran parameter model GSTAR dilakukan menggunakan metode Ordinary Least Squares (OLS). Selanjutnya [4] mengembangkan model GSTAR menjadi GSTARI dan GSTAR-ARCH. Peneliti lain mengembangkan model GSTAR-Kriging untuk peramalan data curah hujan di Jawa Barat [3]. Sedangkan model GSTAR Exogenous (GSTAR-X) dikembangkan oleh [7] dan model GSTARI $(1,1,1)$-Kriging dan penerapannya untuk peramalan debit air sungai Citarum dengan menggunakan OLS dikaji oleh [16]. Penelitian model space time baik model STAR maupun model GSTAR masih terbatas pada lag waktu 1 menggunakan metode OLS. Oleh karena itu, pada penelitian ini penulis mempelajari pengembangan model STARI pada lag spasial 2 dengan metode penaksiran menggunakan metode Maximum Likelihood (MLE) serta menerapkannya pada data debit air sungai Citarum di Jawa Barat.

Berdasarkan dampak yang ditimbulkan dari perubahan debit air sungai Citarum dan keterkaitan antara debit air sungai Citarum terhadap lokasi dan waktu secara simultan, maka penulis menggunakan model STARI untuk memodelkan data debit air sungai Citarum yang memiliki keterkaitan dengan waktu sebelumnya dan lokasi yang saling berdekatan pada data yang tidak stasioner.

\section{METODE PENELITIAN}

Data yang digunakan dalam paper ini adalah data debit air sungai sepanjang Daerah Aliran Sungai (DAS) Citarum dari bulan Januari 2005 sampai Desember 2013. Data tersebut diperoleh dari Pusat Penelitian 
dan Pengembangan Sumber Daya Air (PUSAIR) Bandung di bawah Kementerian Pekerjaan Umum dan Perumahan Rakyat. Data ini dibagi menjadi dua, yaitu data insample dan data outsampel. Data insampel yang digunakan adalah data dari bulan Januari 2005 hingga Desember 2012 atau sebesar 89\% dan data outsampel yang digunakan adalah data dari bulan Januari 2013 hingga Desember 2013 atau sebesar 11\%. Berikut contoh data debit air sungai sepanjang Daerah Aliran Sungai (DAS) Citarum:

Tabel 1. Data Debit Air Sungai Sepanjang DAS Citarum $\left(m^{3} /\right.$ detik)

\begin{tabular}{ccccc}
\hline & Cijalupang-Peundeuy & Cikapundung-Gandok & Cikeruh-Cikuda & Citarum-Majalaya \\
\hline Jan 2005 & 49,42 & 46,51 & 11,15 & 25,81 \\
Feb 2005 & 54,93 & 76,16 & 14,96 & 34,03 \\
Mar 2005 & 45,18 & 41,09 & 19,76 & 21,77 \\
Apr 2005 & 112,6 & 42,08 & 16,07 & 10,06 \\
$\vdots$ & $\vdots$ & $\vdots$ & $\vdots$ & $\vdots$ \\
Des 2013 & 84,77 & 62,25 & 70,44 & 82,55 \\
\hline
\end{tabular}

Sumber data: Pusat Penelitian dan Pengembangan Sumber Daya Air (PUSAIR)

Variabel penelitian yang digunakan dalam paper ini berupa debit air sungai Citarum yang ditentukan berdasarkan cluster dari 8 pos pengamatan dipilih 4 pos pengamatan [16], yaitu:

- $Z_{1}(t)$ : Debit air sungai Citarum di pos pengamatan Cijalupang-Peundeuy (posisi $s_{1}$ )

- $Z_{2}(t)$ : Debit air sungai Citarum di pos pengamatan Cikapundung-Gandok (posisi $s_{2}$ )

- $Z_{3}(t)$ : Debit air sungai Citarum di pos pengamatan Cikeruh-Cikuda (posisi $s_{3}$ )

- $Z_{4}(t)$ : Debit air sungai Citarum di pos pengamatan Citarum-Majalaya (posisi $s_{4}$ )

Keempat pos pengamatan dapat digambarkan pada peta DAS Citarum sebagai berikut:

Keterangan:
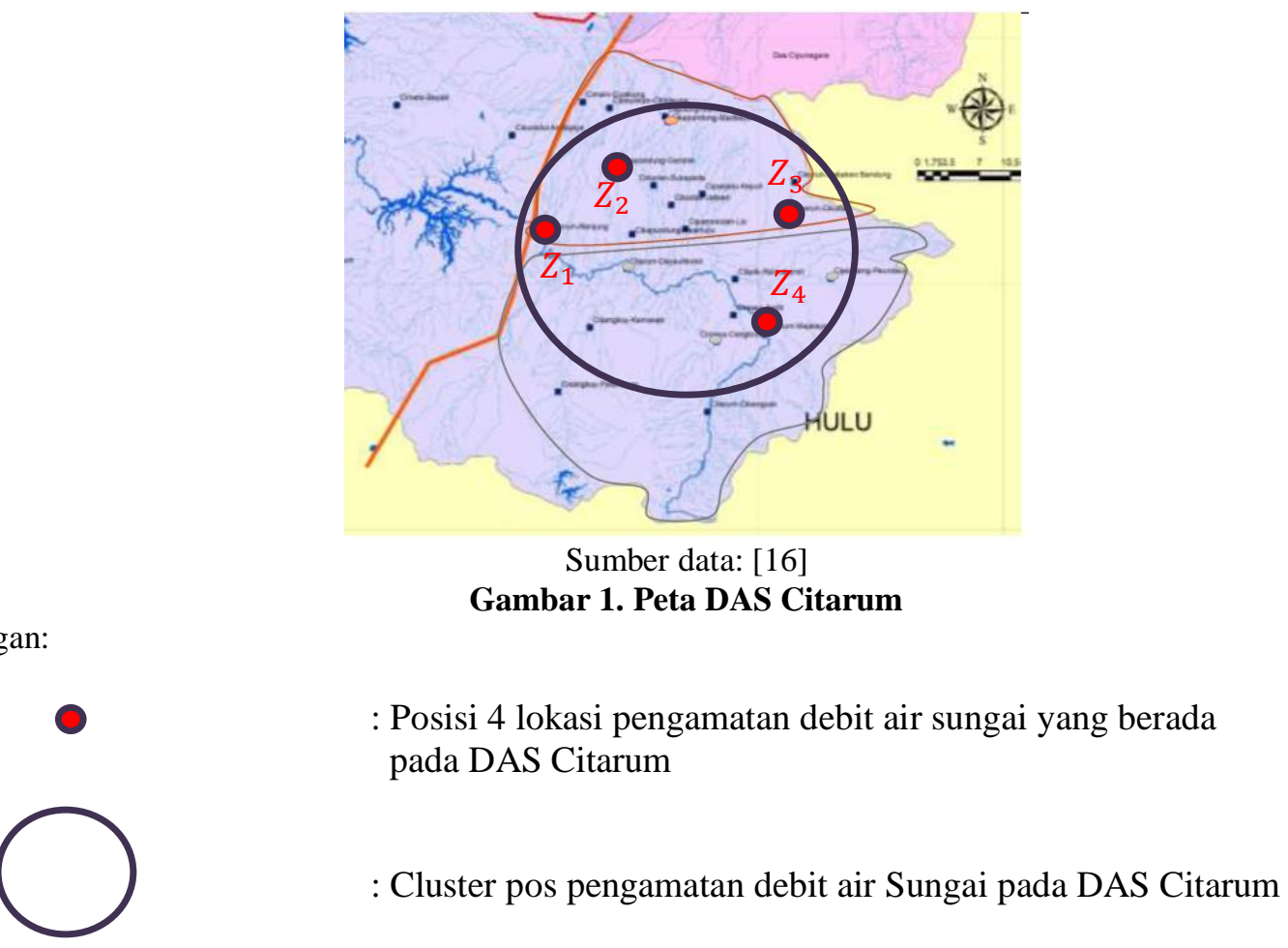

Posisi pos pengamatan pada Gambar 1 di atas selanjutnya digunakan untuk menentukan matriks bobot antar lokasi untuk model STARI. Tahapan analisis yang dilakukan untuk memprediksi debit air sungai Citarum dengan model STARI dalam paper ini adalah sebagai berikut:

1. Mengidentifikasi model data time series dengan melihat melalui plot time series. Pada tahap ini, data time series diplot dan dilihat apakah data tersebut memiliki kemiripan pola untuk setiap lokasinya. 
2. Memeriksa kestasioneran data dengan menggunakan Augmented Dickey-Fuller (ADF) pada masingmasing lokasi dengan software R. Pada tahap ini, data dicek apakah stasioner atau tidak. Asumsi stasioner berguna untuk meminimalisir kesalahan dalam pemodelan. Jika korelogram ACF dari data membentuk pola cut-off (memotong garis) atau tails off (harus secara cepat membentuk sinoidal), maka data diperkirakan stasioner. Sedangkan jika ACF membentuk tails off sacara lambat, maka data dapat diindikasikan sebagai data tidak stasioner [18].

3. Mengidentifikasi orde model ARI dengan software R menggunakan plot ACF dan PACF pada masing-masing lokasi serta menentukan lag spasial.

Apabila nilai estimasi ACF menunjukkan pola menurun secara perlahan dan nilai estimasi PACF membentuk pola cut off pada lag 1 serta adanya proses differencing sebanyak 1 kali maka data tersebut dapat dibentuk menjadi model ARI $(1,1)$ [18].

4. Menentukan matriks bobot seragam melalui matriks jarak antar stasiun pengamatan pada Tabel 2 untuk lag pasial 1 dan lag spasial 2.

Pada tahap ini, pemberian bobot spasial antar lokasi $i$ dan $j$ didasarkan oleh ketetanggaannya. Apabila $i$ bertetangga dengan $j$ maka diberi bobot 1, akan tetapi apabila $i$ tidak bertetangga dengan $j$ maka diberi bobot 0 serta apabila $i=j$ diberi bobot 0 [15].

5. Menaksir parameter dengan Maximum Likelihood (MLE) terhadap gabungan lokasi dan waktu

Model STARI memiliki asumsi error yang berdistribusi normal dapat ditaksir dengan metode MLE, dimana prinsip dari MLE adalah memaksimumkan fungsi $\ln$ likelihood [18].

6. Cek diagnostik dengan melihat quartile-quartile (Q-Q) plot

Cek diagnostik dilakukan untuk mengecek apakah asumsi error sudah terpenuhi atau belum terpenuhi [18].

7. Memprediksi data debit air sungai Citarum.

Melakukan prediksi pada data debit air sungai Citarum dari model yang telah diperoleh.

8. Memeriksa kesesuaian model STARI dengan perhitungan Mean Absolute Persentage Error (MAPE).

Perhitungan MAPE digunakan untuk mengecek kesesuaian dan akurasi model. Semakin kecil MAPE, semakin baik model yang diperoleh.

9. Memperoleh model STARI untuk memprediksi debit air sungai Citarum pada masa yang akan datang di suatu lokasi pos pengamatan dengan memperhitungkan pengaruh lokasi-lokasi lain di sekitar lokasi tertentu.

Dalam menganalisis data debit air sungai Citarum di masing-masing pos pengamatan diasumsikan bahwa jumlah debit air sungai Citarum di pos pengamatan pada suatu bulan tertentu dipengaruhi oleh jumlah debit air sungai Citarum satu bulan sebelumnya pada pos pengamatan tertentu dengan situasi dan kondisi yang diasumsikan konstan, artinya relatif tidak banyak perubahan.

\section{HASIL DAN PEMBAHASAN}

\subsection{Identifikasi Model STARI}

Data debit air sungai Citarum memiliki pola data model AR(1). Model AR(1) yaitu model data time series dimana pengamatan pada waktu $t$ dipengaruhi oleh pengamatan pada waktu sebelumnya $(t-1)$ [18]. Akan tetapi, data debit air sungai Citarum tidak stasioner sehingga perlu dilakukan proses differencing sebanyak 1 kali, sehingga model AR(1) berubah menjadi model ARI $(1,1)$. Data debit air sungai Citarum tidak hanya dipengaruhi oleh waktu, tetapi juga oleh faktor lokasi. Fenomena pengamatan waktu sekarang yang dipengaruhi oleh pengamatan satu waktu sebelumnya di lokasi tersebut dan berada dalam 1 kelompok lokasi berdasarkan jarak terdekat yang pertama antar titik lokasi disebut model STAR(1,1) [15]. Akan tetapi, data debit air sungai Citarum memiliki fenomena pengamatan waktu sekarang yang dipengaruhi oleh pengamatan satu waktu sebelumnya di lokasi tersebut dan berada dalam kelompok kedua berdasarkan jarak terdekat kedua dari titik-titik lokasi pengamatan serta memiliki data yang tidak stasioner sehingga debit air sungai Citarum dapat dimodelkan dengan model STARI $(2,1,1)$. Pada paper ini model yang dikaji difokuskan pada model STARI $(2,1,1)$ yang dituliskan sebagai berikut:

$$
\mathbf{y}(t)_{(N \times 1)}=\varphi_{01} \mathbf{y}(t-1)_{(N \times 1)}+\varphi_{11} \mathbf{w}_{(N \times N)}^{(1)} \mathbf{y}(t-1)_{(N \times 1)}+\varphi_{21} \mathbf{w}_{(N \times N)}^{(2)} \mathbf{y}(t-1)_{(N \times 1)}+\mathbf{e}(t)
$$

dengan $\mathbf{y}(t)=\mathbf{z}(t)-\mathbf{z}(t-1)$ berupa vektor dan $t$ adalah waktu pengamatan debit air sungai serta $N$ adalah banyaknya lokasi, sehingga persamaan (1) dapat dituliskan menjadi persamaan (2) 


$$
\begin{gathered}
\mathbf{z}(t)_{(N \times 1)}-\mathbf{z}(t-1)_{(N \times 1)}=\varphi_{01}\left(\mathbf{z}(t-1)_{(N \times 1)}-\mathbf{z}(t-2)_{(N \times 1)}\right)+\varphi_{11} \mathbf{W}_{(N \times N)}^{(1)} \\
\left(\mathbf{z}(t-1)_{(N \times 1)}-\mathbf{z}(t-2)_{(N \times 1)}\right)+\varphi_{21} \mathbf{W}_{(N \times N)}^{(2)}\left(\mathbf{z}(t-1)_{(N \times 1)}-\mathbf{z}(t-2)_{(N \times 1)}\right)+\mathbf{e}(t)
\end{gathered}
$$

secara umum dengan menggunakan penulisan dalam bentuk model linear pada persaman berikut:

$$
\boldsymbol{y}_{((N \times(T-1)) \times 1)}=\mathbf{X}_{((N \times(T-1)) \times(N \times(T-1)))} \boldsymbol{\beta}_{((N \times(T-1)) \times 1)}+\boldsymbol{\varepsilon}_{((N \times(T-1)) \times 1)}
$$

Selanjutnya persamaan model STARI $(2,1,1)$ pada persamaan (2) dapat dinyatakan sebagai berikut:

$$
\mathbf{y}(t)=\left[\begin{array}{lll}
\mathbf{y}(t-1) & \mathbf{W}^{(1)} \mathbf{y}(t-1) & \mathbf{W}^{(2)} \mathbf{y}(t-1)
\end{array}\right]\left[\begin{array}{l}
\varphi_{01} \\
\varphi_{11} \\
\varphi_{21}
\end{array}\right]+\mathbf{e}(t)
$$

dengan,

$$
\begin{aligned}
& \mathbf{y}=\mathbf{y}(t), \quad \mathbf{X}=\left[\begin{array}{lll}
\mathbf{y}(t-1) & \mathbf{W}^{(1)} \mathbf{y}(t-1) & \mathbf{W}^{(2)} \mathbf{y}(t-1)
\end{array}\right], \quad \boldsymbol{\beta}=\left[\begin{array}{l}
\varphi_{01} \\
\varphi_{11} \\
\varphi_{21}
\end{array}\right], \quad \boldsymbol{\varepsilon}=\mathbf{e}(t) \text { dan asumsi } \\
& \boldsymbol{\varepsilon} \sim N\left(\mathbf{0}, \sigma^{2} \mathbf{I}\right) .
\end{aligned}
$$

Pada kajian ini $N$ adalah 4 pos lokasi pengamatan debit air sungai di DAS Citarum dan $t=1,2, \ldots, 96$ bulan pengamatan debit air sungai di setiap pos pengamatan di DAS Citarum.

\subsection{Penaksiran Parameter Model STARI(2,1,1) dengan Metode Maximum Likelihood (MLE)}

Model STARI $(2,1,1)$ pada persamaan (4) memiliki asumsi error yang berdistribusi normal, sehingga parameter model STARI $(2,1,1)$ dapat ditaksir dengan metode kemungkinan maksimum atau Maximum Likelihood Estimation (MLE). Penaksiran parameter model VARI dengan metode MLE telah dilakukan oleh [8]. Penaksiran parameter MLE model STARI $(2,1,1)$ hampir mirip dengan penaksiran parameter MLE model VARI. Berdasarkan persamaan (3) dan asumsi error berdistribusi Normal, maka persamaan (4) dapat dinyatakan dalam bentuk:

$$
(\mathbf{y}-\mathbf{X} \boldsymbol{\beta}) \sim N\left(\mathbf{0}, \sigma^{2} \mathbf{I}\right)
$$

Fungsi kepadatan peluang untuk persamaan (5) yang nantinya menjadi fungsi likelihood dapat dituliskan:

$$
f(\varepsilon)=\frac{1}{\sigma \sqrt{2 \pi}} \exp \left(-\frac{\varepsilon^{2}}{2 \sigma^{2}}\right)
$$

Selanjutnya fungsi likelihood dituliskan:

$$
\begin{gathered}
L\left(\boldsymbol{\beta}, \sigma_{e}^{2}\right)=\prod_{i=1}^{n} \frac{1}{\sqrt{2 \pi \sigma_{e}^{2}}} \exp \left(-\frac{\varepsilon_{i}^{2}}{2 \sigma_{e}^{2}}\right) \\
\ln \left(L\left(\boldsymbol{\beta}, \sigma_{e}^{2}\right)\right)=-\frac{n}{2} \ln (2 \pi)-\frac{n}{2} \ln \left(\sigma_{e}^{2}\right)-\left(\frac{1}{2 \sigma_{e}^{2}}\right)(\mathbf{y}-\mathbf{X} \boldsymbol{\beta})^{T}(\mathbf{y}-\mathbf{X} \boldsymbol{\beta}) \\
\ln \left(L\left(\boldsymbol{\beta}, \sigma_{e}^{2}\right)\right)=-\frac{n}{2} \ln (2 \pi)-\frac{n}{2} \ln \left(\sigma_{e}^{2}\right)-\ell(\boldsymbol{\beta})
\end{gathered}
$$

dengan

$$
\ell(\boldsymbol{\beta})=\left(\frac{1}{2 \sigma_{e}^{2}}\right)(\mathbf{y}-\mathbf{X} \boldsymbol{\beta})^{T}(\mathbf{y}-\mathbf{X} \boldsymbol{\beta})
$$

Selanjutnya, turunkan persamaan (9) terhadap $\boldsymbol{\beta}$ diperoleh:

$$
\frac{\partial\left(\ln \left(L\left(\boldsymbol{\beta}, \sigma_{e}^{2}\right)\right)\right)}{\partial(\boldsymbol{\beta})}=\frac{\partial \ell(\boldsymbol{\beta})}{\partial(\boldsymbol{\beta})}=0
$$

dan diperoleh vektor penaksir $\boldsymbol{\beta}$, yaitu:

$$
\widehat{\boldsymbol{\beta}}=\left(\mathbf{X}^{T} \mathbf{X}\right)^{-1} \mathbf{X}^{T} \mathbf{y}
$$

Persamaan (11) dapat dituliskan: 


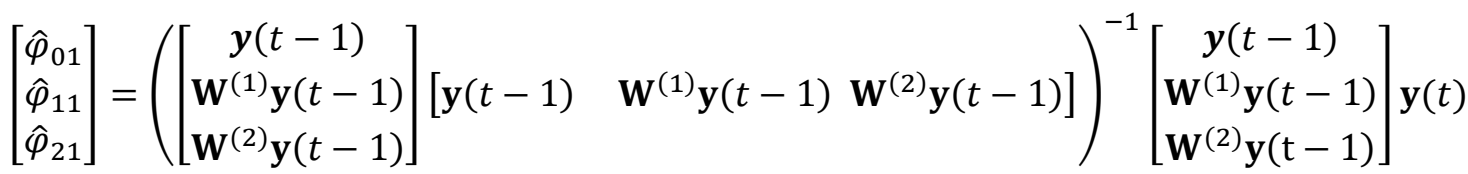

\subsection{Statistika Deskriptif Data Debit Air Sungai Citarum}

Pada paper ini, data yang digunakan adalah data sekunder berupa debit air sungai Citarum bulanan periode Januari 2005-Desember 2013 di empat lokasi pos pengamatan sebanyak 108 data bersumber dari PUSAIR Bandung, dengan data insampel 96 bulan dan data outsampel 12 bulan. Statistika deskriptif mengenai ukuran pemusatan dan penyebaran data disajikan pada Tabel 2.

Tabel 2. Statistika Deskriptif Debit Air Sungai Citarum di Masing-masing Pos Pengamatan $\left(\mathrm{m}^{3} / \mathrm{s}\right)$

\begin{tabular}{lllllll}
\hline Lokasi & Nama & Minimum & Maksimum & Rata-Rata & Variansi & St.Dev. \\
& Pos & & & & & \\
\hline Cijalupang-Peundeuy & Pos 1 & 12,48 & 327,51 & 39,51 & 1529,541 & 39,109 \\
Cikapundung-Gandok & Pos 2 & 18,58 & 110,09 & 41,94 & 237,504 & 15,412 \\
Cikeruh-Cikuda & Pos 3 & 0,012 & 134,186 & 17,576 & 554,418 & 23,546 \\
Citarum-Majalaya & Pos 4 & 0,555 & 185,038 & 32,483 & 996,511 & 31,568 \\
\hline
\end{tabular}

Berdasarkan Tabel 2 diketahui bahwa data debit air sungai Citarum di 4 lokasi pos pengamatan memiliki rata-rata terbesar debit air sungai Citarum, berada di pos 1 yaitu pos pengamatan CijalupangPeundeuy sedangkan rata-rata terkecil berada di pos 3 yaitu pos pengamatan Cikeruh-Cikuda. Jika dilihat pada nilai variansinya, variansi data debit air sungai Citarum memiliki nilai variansi yang relatif tinggi. Hal ini menunjukkan bahwa adanya fluktuasi debit air sungai Citarum di masing-masing pos pengamatan yang relatif tinggi.

Selanjutnya, untuk menggambarkan fenomena debit air sungai Citarum berdasarkan data bulanan di empat lokasi pengamatan dapat dilihat melalui plot time series. Plot time series dapat dilihat pada Gambar 2 berikut ini:

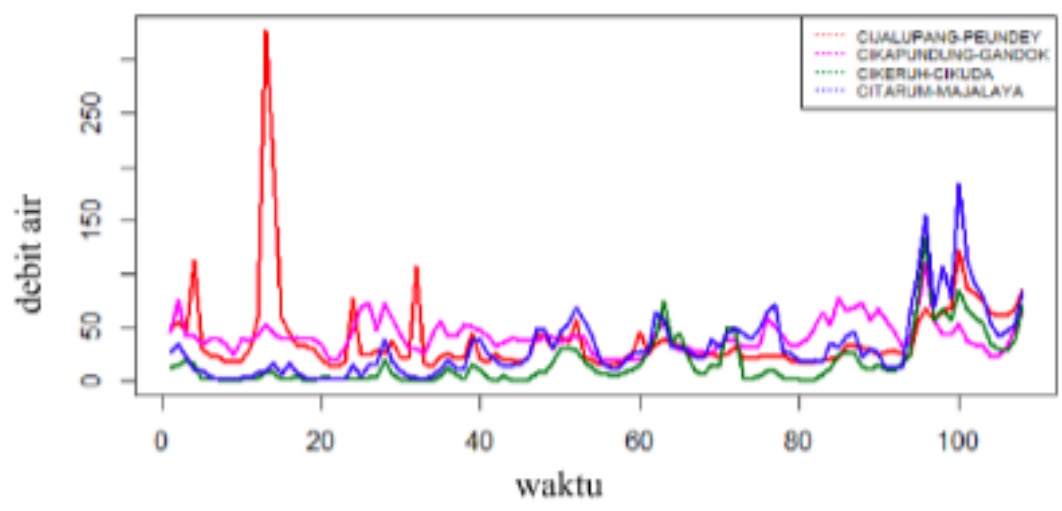

Gambar 2. Plot Time Series Debit Air Sungai Citarum di Empat Lokasi Pengamatan

Gambar 2 menunjukkan bahwa plot time series data debit air Sungai Citarum mengalami fluktuasi dan dari 108 pengamatan di empat lokasi masing-masing memiliki pola fluktuasi debit air yang mirip.

\subsection{Penentuan Matriks Bobot}

Matriks bobot lokasi pada paper ini dilakukan secara subjektif berdasarkan posisi lokasi pos pengamatan yang saling berdekatan seperti ditunjukkan pada pada Gambar 1. Lag spasial 1 ditentukan berdasarkan kedekatan posisi pos pengamatan $s_{1}$ dengan $s_{2}, s_{1}$ dengan $s_{4}, s_{2}$ dengan $s_{3}$ dan $s_{3}$ dengan $s_{4}$. Sedangkan lag spasial 2 menggambarkan kedekatan posisi antara pos pengamatan $s_{1}$ dengan $s_{3}$ dan $s_{2}$ dengan $s_{4}$. Berikut ini disajikan gambar kedekatan posisi lokasi untuk lag spasial 1 dan lag spasial 2 yang digunakan dalam model STARI $(2,1,1)$. 

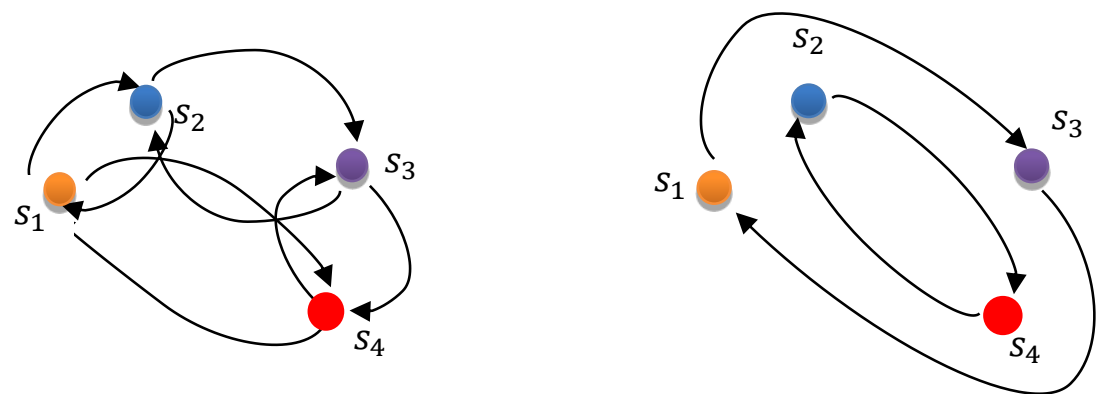

Gambar 3. Lag Spasial 1 dan Lag Spasial 2 Posisi Lokasi Pengamatan Debit Air Sungai Citarum

Berdasarkan Gambar 3 maka matriks bobot lokasi untuk empat pos pengamatan di DAS Citarum untuk lag spasial 1 dan lag spasial 2 dinyatakan sebagai berikut :

$$
\mathbf{W}^{(1)}=\left[\begin{array}{cccc}
0 & 0,5 & 0 & 0,5 \\
0,5 & 0 & 0,5 & 0 \\
0 & 0,5 & 0 & 0,5 \\
0,5 & 0 & 0,5 & 0
\end{array}\right] \text { dan } \mathbf{W}^{(2)}=\left[\begin{array}{llll}
0 & 0 & 1 & 0 \\
0 & 0 & 0 & 1 \\
1 & 0 & 0 & 0 \\
0 & 1 & 0 & 0
\end{array}\right]
$$

Kedua matriks bobot di atas dapat digunakan dengan asumsi karakteristik lokasi pos pengamatan bersifat homogen artinya tidak terdapat banyak perubahan fenomena dari keempat lokasi pengamatan tersebut.

\subsection{Identifikasi Orde Model STARI $(2,1,1)$ Melalui Time Series Univariat}

Plot ACF dan PACF diperoleh dengan bantuan software R disajikan pada Gambar 4 dan Gambar 5.

Series datain[, 1]

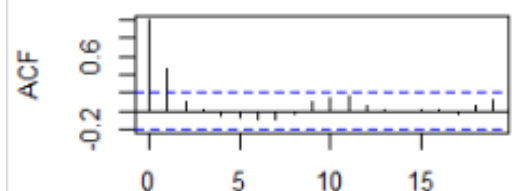

Lag

Series datain[, 3]

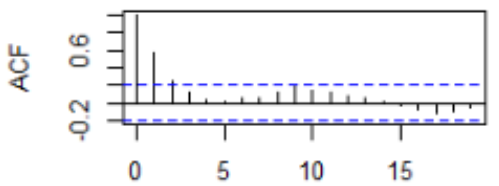

Lag
Series datain[, 2]

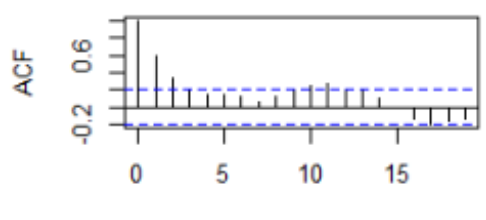

Lag

Series datain[, 4]

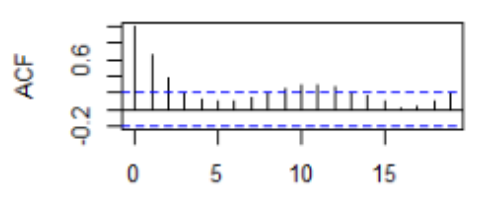

Lag

Gambar 4. Plot ACF Data Debit Air Sungai Citarum 

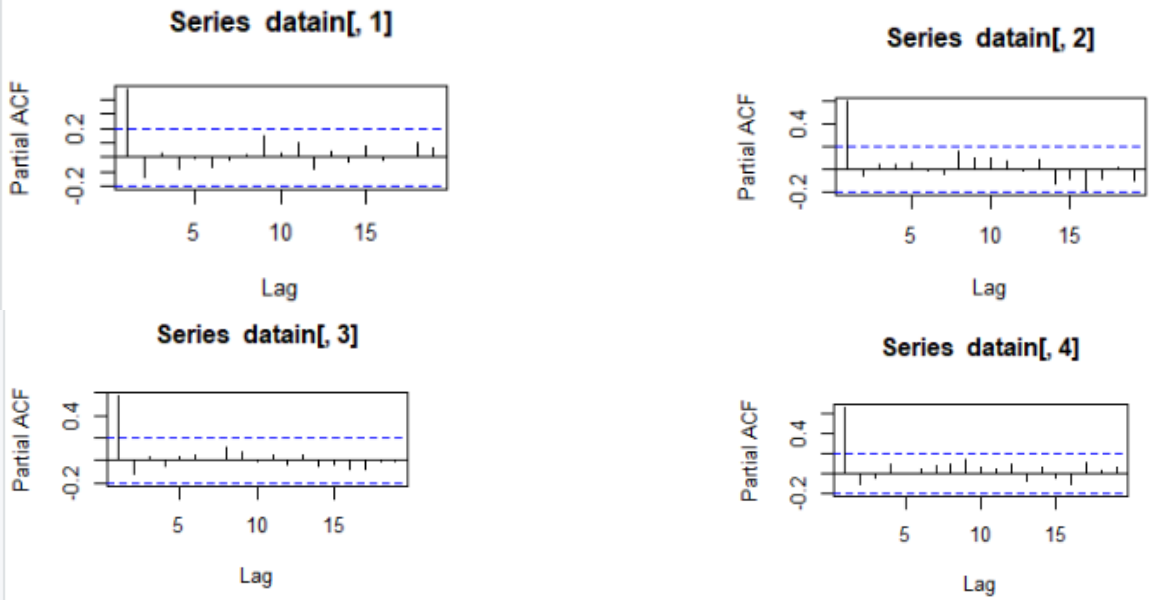

Gambar 5. Plot PACF Data Debit Air Sungai Citarum

Berdasarkan plot ACF pada Gambar 4 dan Gambar 5 terlihat bahwa pada keempat pos pengamatan anak sungai menunjukkan pola dies down atau menurun secara perlahan. Sementara itu, plot PACF menunjukkan pada keempat pos pengamatan anak sungai terpotong pada lag 1. Menurut [18], apabila nilai estimasi ACF menunjukkan pola menurun secara perlahan dan nilai estimasi PACF membentuk pola cut off pada lag 1 serta adanya proses differencing sebanyak 1 kali maka data tersebut dapat dibentuk menjadi model ARI $(1,1)$. Apabila dilihat dari pola data tersebut, keempat lokasi pos pengamatan debit air sungai Citarum dapat membentuk model ARI $(1,1)$.

\subsection{Kestasioneran Data Debit Air Sungai Citarum}

Identifikasi kestasioneran data dalam rata-rata selain dapat dilihat langsung pada plot data, tetapi juga dapat dilakukan uji Augmented Dickey Fuller (ADF) dengan bantuan software R untuk model time series univariat AR(1) sebelum differencing dan ARI $(1,1)$ setelah differencing orde 1. Hasil ADF test data debit air sungai Citarum sebagai berikut:

Tabel 3. ADF Test Data Debit Air Sungai Citarum Sebelum Differencing dan Sesudah Differencing

\begin{tabular}{l|c|c|c|c}
\hline \multirow{2}{*}{ Lokasi } & \multicolumn{2}{|c|}{ Uji ADF sebelum differencing } & \multicolumn{2}{c}{ Uji ADF setelah differencing 1 kali } \\
\cline { 2 - 5 } & p-value & Kesimpulan & p-value & Kesimpulan \\
\hline Pos 1 $\left(s_{1}\right)$ & 0,01 & Data stasioner & 0,01 & Data stasioner \\
Pos 2 $\left(s_{2}\right)$ & 0,49 & Data tidak stasioner & 0,01 & Data stasioner \\
Pos 3 $\left(s_{3}\right)$ & 0,52 & Data tidak stasioner & 0,02 & Data stasioner \\
Pos 4 $\left(s_{4}\right)$ & 0,02 & Data stasioner & 0,04 & Data stasioner \\
\hline
\end{tabular}

Berdasarkan Tabel 3 terlihat bahwa untuk data debit air sungai Citarum pada pos 2 dan 3 memiliki pvalue lebih besar dari $\alpha=5 \%$. Apabila $p$-value $<$ taraf signifikan $\alpha$ maka hipotesis ditolak sehingga dapat disimpulkan bahwa data tidak mengandung unit root [18]. Oleh karena itu, data debit air sungai Citarum pada pos 2 dan 3 tidak stasioner karena $p$-value lebih besar dari $\alpha=5 \%$. Apabila data tidak stasioner, maka untuk membuat data menjadi stasioner dapat dilakukan proses differencing (pembedaan). Setelah dilakukan proses differencing sebanyak 1 kali diperoleh $p$-value yang kurang dari $\alpha=5 \%$, sehingga $H_{0}$ ditolak atau tidak mengandung akar unit.

\subsection{Model STARI $(2,1,1)$ pada Data Debit Air Sungai Citarum}

Berdasarkan hasil penentuan identifikasi model, keempat lokasi mpengamatan memiliki model ARI(1,1), maka untuk model lokasi waktu secara simultan diperoleh model STARI. Untuk lag spasial 1 diperoleh model STARI $(1,1,1)$ dan untuk lag spasial 2 diperoleh model STARI $(2,1,1)$. Taksiran parameter untuk model STARI $(2,1,1)$ untuk data debit air sungai Citarum diperoleh sebagai berikut: 
Tabel 4. Taksiran Parameter Model STARI $(2,1,1)$

\begin{tabular}{cc}
\hline Penaksir & Taksiran \\
\hline$\hat{\varphi}_{01}$ & 0,26882 \\
$\hat{\varphi}_{11}$ & 0,35486 \\
$\hat{\varphi}_{21}$ & 0,29497 \\
\hline
\end{tabular}

Penaksir $\hat{\varphi}_{01}$ menunjukkan bahwa debit air sungai Citarum pada waktu $t$ di lokasi yang sama adalah sebesar 26,882\%. Sedangkan penaksir $\hat{\varphi}_{11}$ menunjukkan pengaruh debit air sungai Citarum pada satu bulan sebelumnya terhadap lokasi di sekitarnya yang berada dalam satu kelompok adalah sebesar $35,486 \%$ dan penaksir $\hat{\varphi}_{21}$ menunjukkan pengaruh debit air sungai Citarum pada satu bulan sebelumnya terhadap lokasi di sekitarnya yang berada dalam dua kelompok adalah sebesar 29,497\%.

Berdasarkan parameter yang telah diperoleh, selanjutnya dapat dibentuk persamaan model STARI $(2,1,1)$ data debit air sungai Citarum di Provinsi Jawa Barat menggunakan matriks bobot $\mathbf{W}^{(1)}$ dan $\mathbf{W}^{(2)}$ adalah sebagai berikut:

$\left[\begin{array}{l}\widehat{y_{1}}(t) \\ \widehat{y_{2}}(t) \\ \widehat{y_{3}}(t) \\ \widehat{y_{4}}(t)\end{array}\right]=0,26882\left[\begin{array}{l}y_{1}(t-1) \\ y_{2}(t-1) \\ y_{3}(t-1) \\ y_{4}(t-1)\end{array}\right]+0,35486\left[\begin{array}{cccc}0 & 0,5 & 0 & 0,5 \\ 0,5 & 0 & 0,5 & 0 \\ 0 & 0,5 & 0 & 0,5 \\ 0,5 & 0 & 0,5 & 0\end{array}\right]\left[\begin{array}{l}y_{1}(t-1) \\ y_{2}(t-1) \\ y_{3}(t-1) \\ y_{4}(t-1)\end{array}\right]+0,29497\left[\begin{array}{llll}0 & 0 & 1 & 0 \\ 0 & 0 & 0 & 1 \\ 1 & 0 & 0 & 0 \\ 0 & 1 & 0 & 0\end{array}\right]\left[\begin{array}{l}y_{1}(t-1) \\ y_{2}(t-1) \\ y_{3}(t-1) \\ y_{4}(t-1)\end{array}\right]$

Secara terperinci untuk setiap pos pengamatan dapat dijelaskan sebagai berikut:

A. Persamaan model STARI $(2,1,1)$ pos pengamatan Cijalupang-Peundeuy $\left(s_{1}\right)$

$$
\widehat{y_{1}}(t)=0,26882 y_{1}(t-1)+0,17743 y_{2}(t-1)+0,17743 y_{4}(t-1)+0,29497 y_{3}(t-1)
$$

B. Persamaan model STARI $(2,1,1)$ pos pengamatan Cikapundung-Gandok $\left(s_{2}\right)$

$$
\widehat{y_{2}}(t)=0,26882 y_{2}(t-1)+0,17743 y_{1}(t-1)+0,17743 y_{3}(t-1)+0,29497 y_{4}(t-1)
$$

C. Persamaan model STARI $(2,1,1)$ pos pengamatan Cikeruh-Cikuda $\left(s_{3}\right)$

$$
\widehat{y_{3}}(t)=0,26882 y_{3}(t-1)+0,17743 y_{2}(t-1)+0,17743 y_{4}(t-1)+0,29497 y_{1}(t-1)
$$

D. Persamaan model STARI $(2,1,1)$ pos pengamatan Citarum-Majalaya $\left(s_{4}\right)$

$$
\widehat{y_{4}}(t)=0,26882 y_{4}(t-1)+0,17743 y_{1}(t-1)+0,17743 y_{3}(t-1)+0,29497 y_{2}(t-1)
$$

dengan $\mathbf{y}(t)=\mathbf{z}(t)-\mathbf{z}(t-1)$ seperti pada persamaan (1).

\subsection{Nilai Prediksi Debit Air Sungai Citarum di Empat Lokasi Pengamatan}

Hasil Prediksi berdasarkan model STARI $(2,1,1)$ yang diperoleh dari persamaan (14), (15), (16), dan (17) dengan nilai aktual debit air sungai Citarum dapat disajikan pada gambar berikut ini:

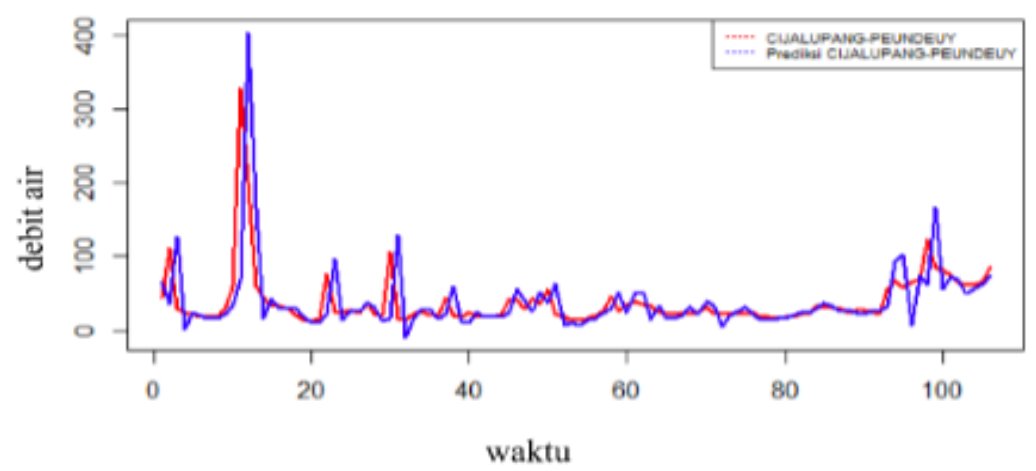

Gambar 6. Plot Time Series Data Debit Air Sungai Citarum dan Data Prediksi Model STARI(2,1,1) untuk Pos Pengamatan Cijalupang-Peundeuy 


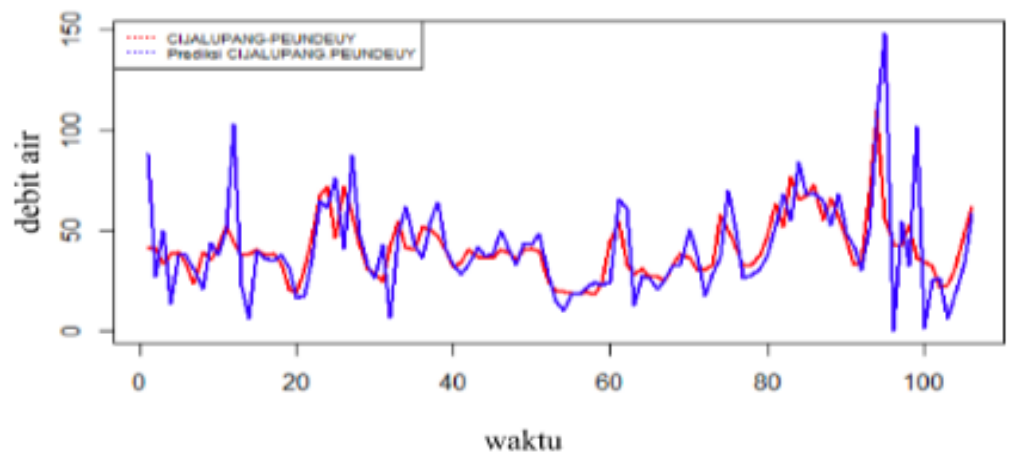

Gambar 7. Plot Time Series Data Debit Air Sungai Citarum dan Data Prediksi Model STARI(2,1,1) untuk Pos Pengamatan Cikapundung-Gandok

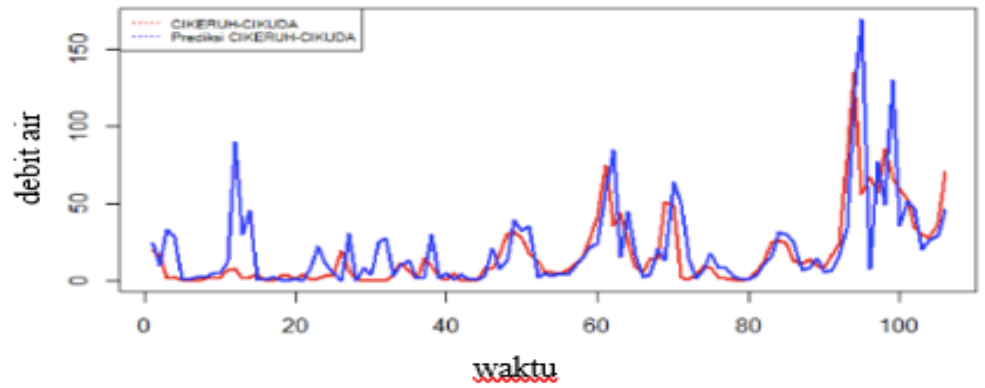

Gambar 8. Plot Time Series Data Debit Air Sungai Citarum dan Data Prediksi Model STARI(2,1,1) untuk Pos Pengamatan Cikeruh-Cikuda

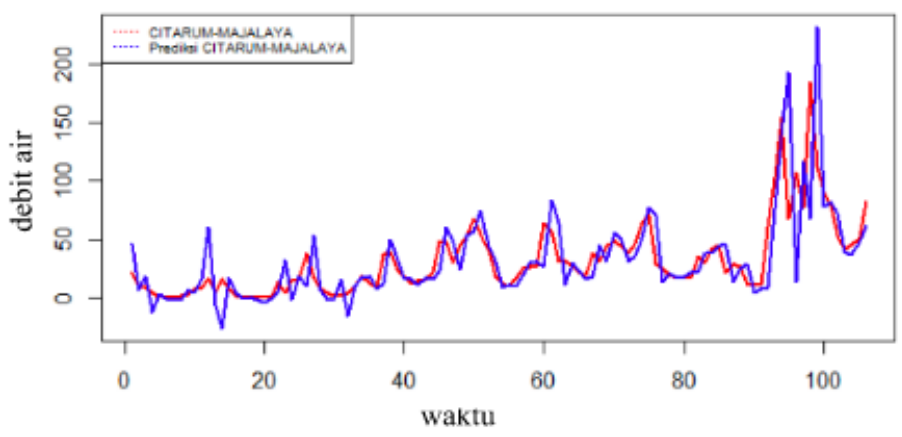

Gambar 9. Plot Time Series Data Debit Air Sungai Citarum dan Data Prediksi Model STARI(2,1,1) untuk Pos Pengamatan Citarum-Majalaya

Berdasarkan Gambar 6, Gambar 7, Gambar 8, dan Gambar 9 dari keempat lokasi pengamatan dapat dilihat bahwa plot data prediksi hampir mendekati plot data aktualnya. Hal ini menunjukkan model STARI $(2,1,1)$ dengan melibatkan lokasi dan waktu secara simultan memberikan hampiran yang baik untuk fenomena data debit air Sungai Citarum

Selanjutnya dihitung nilai MAPE dari keempat lokasi pengamatan sebagai berikut:

Tabel 5. Nilai MAPE Model STARI $(2,1,1)$ pada Keempat Lokasi Pengamatan

\begin{tabular}{c|c}
\hline Pos Pengamatan & MAPE \\
\hline Cijalupang-Peundeuy & $0,5069 \%$ \\
Cikapundung-Gandok & $2,2607 \%$ \\
Cikeruh-Cikuda & $0,4555 \%$ \\
Citarum-Majalaya & $1,7531 \%$ \\
\hline
\end{tabular}


Berdasarkan Tabel 5 di atas dapat diketahui bahwa Nilai MAPE dari keempat lokasi pengamatan kurang dari $10 \%$, sehingga dapat dikatakan model STARI $(2,1,1)$ memiliki kesesuaian untuk menggambarkan fenomena variasi debit air sungai Citarum dengan melibatkan fenomena lokasi waktu secara simultan.

\section{KESIMPULAN}

Berdasarkan pembahasan yang telah dilakukan dapat diperoleh simpulan bahwa model STARI $(2,1,1)$ memiliki asumsi error yang berdistribusi normal dengan rata-rata $\mathbf{0}$ dan variansi $\sigma^{2} \mathbf{I}$ menggunakan metode MLE menghasilkan taksiran parameter berupa $\hat{\varphi}_{01}, \hat{\varphi}_{11}$, dan $\hat{\varphi}_{21}$. Selain itu, penerapan model STARI $(2,1,1)$ untuk memprediksi debit air sungai Citarum di keempat lokasi pengamatan menghasilkan model dengan pola kemiripan yang sesuai satu sama lain. Hal ini ditunjukkan dengan nilai MAPE yang kurang dari $10 \%$ di keempat lokasi pengamatan. Dengan demikian, model STARI $(2,1,1)$ dapat dijadikan bahan rekomendasi kepada instansi yang terkait dalam memprediksi debit air sungai Citarum di DAS Citarum di wilayah Provinsi Jawa Barat.

\section{UCAPAN TERIMA KASIH}

Penulis mengucapkan terima kasih kepada Rektor Universitas Padjadjaran yang telah memberikan dukungan dana penelitian melalui Academic Leadership Grant tahun 2019 dengan nomor kontrak 3330/UN6.D/LT/ 2019 serta Staf PUSAIR Bandung atas data dan diskusi hasil penelitian.

\section{DAFTAR PUSTAKA}

[1] Adm. D. L. H. Jabar., "Citarum Semakin Menantang”, DLH Jabar, 9 Januari 2019, [Online]. Tersedia: http://dlh.jabarprov.go.id/index.php/layanan/k2-categories-2/item/95-citarum-semakin-menantang [Diakses: 1911-2019]

[2] A. D. Cliff and J. K. Ord, "Model Building and The Analysis of Spatial Pattern in Human Geography, J. Roy. Statist. Soc. B, vol. 37, no. 3, p. 297-348, 1975.

[3] A. S. Abdullah, S. Matoha, D. A. Lubis, A. N. Falah, I. G. N. M. Jaya, E. Hermawan, "Implementation of Generalized Space Time Autoregressive (GSTAR)-Kriging Model for Predicting Rainfall Data at Unobserved Locations in West Java," App. Math. and Inf. Sci., vol. 12, no.3 , p. 607-615, 2018.

[4] B. N. Ruchjana, "Pengembangan Model Spatio Temporal dan Aplikasinya," Pros. Sem. Nas. Mat. dan Pend. Mat. UIN Rad. Intan Lamp., vol. 2, no.1, p. 1-19, 2019.

[5] B. N. Ruchjana, "Suatu Model Generalisasi Space-Time Autoregresif dan Penerapannya pada Produksi Minyak Bumi," Ph.D. dissertation, Institut Teknologi Bandung, Bandung, Indonesia, 2002.

[6] B. N. Ruchjana, S. A. Borovkova, and H. P. Lopuhaa, "Least Squares Estimation of Generalized Space Time AutoRegressive (GSTAR) Model and Its Properties," AIP Conf. Proc. vol. 1450. no.1, p. 61-64, 2012.

[7] D. Astuti, B. N. Ruchjana, "Generalized Space Time AutoRegressive with Exogenous Variable Model and Its Application,” J. Phys.: Conf. Ser. 893 012038, 2013.

[8] D. A. Wulandari, N. Gusriani, B.N. Ruchjana, "Penaksiran Parameter Model Vector Autoregressive Integrated (VARI) dengan Metode MLE dan Penerapannya pada Data Indeks Harga Konsumen,” indo MS Jour. on Stat., vol.2, no. 1, p.27-37, 2014.

[9] E. Suryamah, B. N. Ruchjana, and K. Joebaedi, “Kajian Matriks Bobot Lokasi Model Space Time AutoRegresi (STAR)," J. Mat. Integr., vol. 9, no. 2, p. 119-130, 2013.

[10] F.B. Wijaya, I. M. Sumertajaya, Erfiani, "Comparison of Autoregressive (AR), Vector Autoregressive (VAR), Space Time Autoregressive (STAR) and Generalized Space Time Autoregressive (GSTAR) in Forcasting (Case: Simulation studi with Autoregressive pattern)," Int. Jour. of Appl. Engineer. Research, vol. 10, no. 21, p.4238842395, 2015.

[11] G. E. P. Box and G. M. Jenkins, “Time Series Analysis, Forecasting and Control, Holden-Day, Inc. San Fransisco. 1976. 
[12] K. Joebaedi, K. Parmikanti, and Badrulfalah, "First Order Space Time Autoregressive Stationary Model on Petroleum Data," EKSAKTA, vol. 19, no. 2, p. 62-69, 2018.

[13] K. Parmikanti, K. Joebaedi, and I. Irianingsih, "Model STAR dengan Bobot Seragam Sebagai Pendeteksi Debit Air Sungai Citarum,” J. Mat. Integratif, vol. 8, no. 2, p. 81-88, 2016.

[14] N. Y. Zahroh, and S. A. Syafira, "Identifikasi Kekeringan Hidrologi di DAS Citarum Hulu," J. Sains \& Tek. Mod. Cuaca, vol. 16, no. 1, p. 21-27, 2015.

[15] P. E. Pfeifer and S. J. Deutsch, "A Three-Stage Iterative Procedure for Space-Time A Three-Stage Iterative Procedure for Space-Time," Tecnometrics, vol. 22, no. 1, p. 35-47, 1980.

[16] R. Silvi, "Pengembangan Model Clustering GTARI-KRIGING dan Penerapannya pada Debit Air Sungai Citarum," Master. Theses, Universitas Padjadjaran, Bandung, Indonesia, 2019.

[17] S. A. Borovkova, H. P. Lopuhaa, and B. N. Ruchjana, "Consistency and Asymptotic Normality of Least Squares Estimators in Generalized STAR Models," Stat. Neerlandica, vol. 62 no. 4, p. 402-508, 2008.

[18] W. W. S. Wei, " Time Series Analysis Univariate and Multivariate Method, Second Edition, USA: Addison-Wesley Publishing Company, 2006. 